\title{
Phylogenetic placement of the Cyrtolophosididae Stokes, 1888 (Ciliophora; Colpodea) and neotypification of Aristerostoma marinum Kahl, 1931
}

Correspondence Thorsten Stoeck stoeck@rhrk.uni-kl.de

\author{
Micah Dunthorn, ${ }^{1} \dagger$ Marion Eppinger, ${ }^{2} \dagger$ M. V. Julian Schwarz, ${ }^{2}$ \\ Michael Schweikert, ${ }^{3}$ Jens Boenigk, ${ }^{4}$ Laura A. Katz ${ }^{1,5}$ \\ and Thorsten Stoeck ${ }^{2}$
}

${ }^{1}$ Graduate Program in Organismic and Evolutionary Biology, University of Massachusetts, Amherst,
MA 01003, USA
${ }^{2}$ Department of Ecology, University of Kaiserslautern, Erwin-Schroedinger-Strasse 14, D-67653
Kaiserslautern, Germany
${ }^{3}$ Department of Zoology, Biological Institute, University of Stuttgart, Pfaffenwaldring 57, D-67633
Stuttgart, Germany
${ }^{4}$ Austrian Academy of Sciences, Institute for Limnology, Mondseestr. 9, A-5310 Mondsee, Austria
${ }^{5}$ Department of Biological Sciences, Smith College, College Road, Northampton, MA 01063, USA

The ciliate family Cyrtolophosididae Stokes, 1888 contains species that are poorly known from both the morphological and molecular perspectives. To further our understanding of this family, one species, Aristerostoma marinum Kahl, 1931, was redescribed. Cells in our population had a mean in vivo size of $15 \times 8 \mu \mathrm{m}$. There were six rows of somatic kineties, as well as six dorsal kinetids belonging to sparsely ciliated somatic kineties. The oral apparatus comprised a bipartite paroral membrane and four adoral organelles. The optimal ecological tolerances for $\mathrm{pH}$ and $\mathrm{O}_{2}$ matched those of the environment in which the specimens were collected, but were different for salinity and temperature. To further test the phylogenetic placement of the family

Cyrtolophosididae with increased taxon sampling, the small subunit rDNA of three morphospecies was characterized: A. marinum, Aristerostoma sp. ATCC 50986 and Pseudocyrtolophopsis alpestris. Unconstrained and constrained molecular analyses supported the non-monophyly of the order Cyrtolophosidida. The family Cyrtolophosididae fell out separately from the rest of its order. Haplotypes from previous environmental studies were also placed in a phylogenetic context within the class Colpodea.

\section{INTRODUCTION}

Like other taxa in the class Colpodea Lynn and Small, 1981, the taxonomic history of the family Cyrtolophosididae Stokes, 1888 is one of shifting classifications. Members of the group were originally placed in the family Frontoniidae by Kahl (1931) and later in the family Tetrahymenidae by Corliss (1961). Foissner (1978) used silverline patterns and Didier et al. (1980), Lynn (1981) and de Puytorac et al.

†These authors contributed equally to this work.

Abbreviations: ASW, artificial seawater; ML, maximum-likelihood; MP, maximum-parsimony; SEM, scanning electron microscopy; SSU-rDNA, small subunit ribosomal DNA.

The GenBank/EMBL/DDBJ accession numbers for the novel SSUrDNA gene sequences determined in this study are indicated in Table 1.
(1979) used transmission electron micrographs of kinetid ultrastructure to link this family with other members of the class Colpodea. The family Cyrtolophosididae was then placed in the order Cyrtolophosidida with other genera, such as Platyophrya and Sagittaria, that have micronuclei and macronuclei that share an outer membrane of the nuclear envelope (Foissner, 1985, 1993).

The family Cyrtolophosididae is currently diagnosed with a number of morphological characters: species have a bipartite paroral membrane, a 'colpodid' silverline pattern and a non-ciliated kinety on the right margin of their adoral organelles (Foissner, 1993). Morphological variation among the four described genera in the family, Aristerostoma, Cyrtolophosis, Plesiocaryon and Pseudocyrtolophosis, is not as distinct; Foissner (1993) has even suggested that 
they might need to be synonymized. Most species are relatively small, $20-35 \times 15 \mu \mathrm{m}$, with a few living in presumably mucocyst-derived tubes (Foissner, 1993). Some of these, such as Aristerostoma marinum (part of the focus of this manuscript), lack modern descriptions and silver impregnations.

The phylogenetic placement of the family Cyrtolophosididae has recently been questioned. In a molecular analysis of all orders within the class Colpodea using small subunit rDNA (SSU-rDNA) sequences, two Cyrtolophosis mucicola sequences branched separately from the rest of its morphologically defined order (Dunthorn et al., 2008). This result challenges the use of the shared outer membranes of the nuclear envelopes to unite the order Cyrtolophosidida. The non-monophyletic SSU-rDNA topology of the order, though, requires further evaluation with increased taxon sampling.

Here we redescribe A. marinum and a new name-bearing type is designated. We also move sampling beyond the only one sequenced species, C. mucicola, and further test the monophyly of the order Cyrtolophosidida with three previously uncharacterized morphospecies in two genera using SSU-rDNA phylogenetic analyses. Morphological and molecular hypotheses are compared with constrained analyses and possible issues leading to differences between the morphological and molecular hypotheses are examined. Furthermore, we place GenBank accessions from previous SSU-rDNA environmental surveys in the context of our increased taxon sampling within the family Cyrtolophosididae.

\section{METHODS}

Taxon sampling. Three morphospecies in the family Cyrtolophosididae were isolated for this study and their SSU-rDNA was sequenced (Table 1). A. marinum was collected from surface waters of the Framvaren Fjord in south-west Norway $\left(58^{\circ} 09^{\prime} \mathrm{N}\right.$ $\left.06^{\circ} 55^{\prime} \mathrm{E}\right)$. Pure cultures for a redescription of this species were established using Schmaltz-Pratt medium (per litre: $0.01 \mathrm{~g}$ $\mathrm{K}_{2} \mathrm{HPO}_{4} \cdot 3 \mathrm{H}_{2} \mathrm{O}, \quad 0.1 \mathrm{~g} \quad \mathrm{KNO}_{3}, \quad 1.45 \mathrm{~g} \quad \mathrm{CaCl}_{2} \cdot 2 \mathrm{H}_{2} \mathrm{O}, \quad 6.92 \mathrm{~g}$ $\mathrm{MgSO}_{4} \cdot 7 \mathrm{H}_{2} \mathrm{O}, 5.51 \mathrm{~g} \mathrm{MgCl}_{2} \cdot 6 \mathrm{H}_{2} \mathrm{O}, 0.67 \mathrm{~g} \mathrm{KCl}$ and $28.15 \mathrm{~g} \mathrm{NaCl}$ ) with heat-inactivated Klebsiella minuta as a food source. Aristerostoma sp. ATCC 50986 was originally collected from a marine environment in the Great Marsh, Delaware, USA, where grey mud was found mixed with roots, sand and clay. This isolate will be examined morphologically elsewhere. Pseudocyrtolophopsis alpestris was collected from the litter of a spruce forest in Lambrechtshausen, near Salzburg, Austria, by W. Foissner.

With the addition of the two GenBank accessions for C. mucicola and sequences from environmental studies (Table 1), there are now eight exemplars in the family Cyrtolophosididae. Sequences from the rest of the order Cyrtolophosidida and from the other Colpodea orders are from GenBank (Table 1). Outgroup selection was based on previous studies.

Light and electron microscopy. For light microscopy of living and stained cells, a Zeiss Axioplan 2 microscope was used. Protargol impregnation followed the method of Foissner et al. (1999), with the cells fixed in $1 \mathrm{ml}$ aqueous saturated $\mathrm{HgCl}_{2}$ with $100 \mu$ l Bouin's fluid
Table 1. Taxon sampling and GenBank accession numbers used in this study

Newly sequenced taxa are in bold.

\begin{tabular}{|c|c|}
\hline Taxon & GenBank Accession no. \\
\hline \multicolumn{2}{|l|}{ Colpodea: } \\
\hline Aristerostoma marinum & EU264562 \\
\hline Aristerostoma sp. & EU264563 \\
\hline Bardeliella pulchra & EU039884 \\
\hline Bresslaua vorax & AF060453 \\
\hline Bresslauides discoideus & EU039885 \\
\hline Bryometopus atypicus & EU039886 \\
\hline Bryometopus pseudochilodon & EU039887 \\
\hline Bryometopus sphagni & AF060455 \\
\hline Bursaria sp. 1 & EU039889 \\
\hline Bursaria sp. 2 A & EU039890 \\
\hline Bursaria sp. 2 B & EU039891 \\
\hline Bursaria truncatella & U82204 \\
\hline Chain-forming colpodid & AY398684 \\
\hline Colpoda aspera & EU039892 \\
\hline Colpoda cucullus & EU039893 \\
\hline Colpoda inflata & M97908 \\
\hline Colpoda steinii & DQ388599 \\
\hline Colpoda henneguyi & EU039894 \\
\hline Colpoda lucida & EU039895 \\
\hline Colpoda magna & EU039896 \\
\hline Colpoda minima & EU039897 \\
\hline Cyrtolophosis mucicola Austria & EU039899 \\
\hline Cyrtolophosis mucicola Brazil & EU039898 \\
\hline Hausmanniella discoidea & EU039900 \\
\hline Ilsiella palustris & EU039901 \\
\hline Mykophagophrys terricola & EU039902 \\
\hline Notoxoma parabryophryides & EU039903 \\
\hline Ottowphrya dragescoi & EU039904 \\
\hline Platyophrya-like sp. & EU039905 \\
\hline Platyophrya sp. & EU039906 \\
\hline Platyophrya vorax & AF060454 \\
\hline Pseudoplatyophrya nana & AF060452 \\
\hline Pseudocyrtolophopsis alpestris & EU264564 \\
\hline Rostrophrya sp. & EU039907 \\
\hline Sagittaria sp. & EU039908 \\
\hline Sorogena stoianovitchae & AF300285 \\
\hline HAVOmet-euk $43^{\star}$ & EF032797 \\
\hline $\mathrm{LKM}^{*} 3^{*}$ & AJ130861 \\
\hline PAA10AU2004* & DQ244029 \\
\hline \multicolumn{2}{|l|}{ Outgroups: } \\
\hline Coleps hirtus & U97109 \\
\hline Furgasonia blochmanni & X65150 \\
\hline Obertrumia georgiana & X65149 \\
\hline Orthodonella apohamatus & DQ232761 \\
\hline Prorodon teres & X71140 \\
\hline Pseudomicrothorax dubius & X65151 \\
\hline
\end{tabular}

*Sequences from environmental sampling.

(cell volume/fixative volume 1:1,30 min, room temperature). Due to cell sensitivity, a high salt concentration in the medium (leading to the formation of precipitates during processing) and a mucus shell covering the organisms (mucocysts, see Results), other staining and 
impregnation methods failed (e.g. silver nitrate impregnation with the Chatton-Lwoff technique and silver carbonate impregnation with the Fernandes-Galiano technique for saltwater ciliates). All images from living, fixed and stained cells were taken by a QImager Microcam (Intas) and QCapture software (http://www.qimaging.com). For further image processing, Adobe Photoshop 7.0 and ImageJ 1.32 (http://rsb.info.nih.gov/ij/) were used.

For scanning electron microscopy (SEM), cells were processed following the method of Stoeck et al. (2005) with slight modifications for fixation: cells/fixative, $1: 1$; osmium tetroxide fixative $[2 \%$ in artificial seawater (ASW; 36\% ) and ASW following Stetter et al. (1983) for $60 \mathrm{~min}$ at room temperature]. Stubs with fixed and dehydrated cells were coated with gold (Edwards E306) and observed with a Zeiss DSM940A instrument (Carl Zeiss GmbH).

Preparation of cells for transmission electron microscopy (TEM) followed the method of Stoeck et al. (2005) with slight modifications in the fixation procedure: a culture aliquot was first fixed with glutaraldehyde $\left(2.5 \%\right.$ final concentration) for $60 \mathrm{~min}$ at $4{ }^{\circ} \mathrm{C}$. Cells were pelleted and embedded in a $4 \%$ low-melt sea-prep agarose (Roth) (Reize \& Melkonian, 1989) with $4 \%$ osmium tetroxide in ASW for $60 \mathrm{~min}$ in order to concentrate and handle the small target cells. Ultrathin sections were investigated with a Zeiss EM10 (Carl Zeiss $\mathrm{GmbH}$ ) and documented on Kodak 4489 film (Eastman Kodak).

Terminology. Terminology follows Corliss (1979), Foissner (1993) and the International Code of Zoological Nomenclature (ICZN, 1999). In designating a new type specimen, we follow Foissner (2002) by allowing the new name bearer to be from a different location than the specimen originally described by Kahl (1931).

Autecology. The ecological tolerances of A. marinum towards four parameters $\left(\% \mathrm{O}_{2}\right.$ in the headspace gas, $\mathrm{pH}, \%$ salinity and temperature) were experimentally tested in $2 \mathrm{ml}$ batch incubations. Cell activity was measured by counting moving and/or dividing cells under a dissection microscope within $24,48,72,96$ and $168 \mathrm{~h}$ periods after inoculation. The cultures were gradually adapted to higher/lower $\mathrm{pH}$, salinity and temperature as outlined by Stoeck et al. (2005).

All incubations were inoculated in six $2 \mathrm{ml}$ parallels [six wells on a 24well plate (Greiner)] in chemically adjusted Schmaltz-Pratt medium at room temperature (with the exception of the temperature experiment). Salinity was changed by the addition of $1 \mathrm{M} \mathrm{NaCl}$ or Volvic mineral water. Changes in $\mathrm{pH}$ were made by the addition of $1 \mathrm{M} \mathrm{NaCO}_{3}$ or $1 \mathrm{M} \mathrm{KH}_{2} \mathrm{PO}_{4}$. The cells were inoculated after $\mathrm{pH}$ stabilization $(24 \mathrm{~h})$. Heat-deactivated $\mathrm{K}$. minuta were added as a food source at a saturated concentration $\left(10^{8}-10^{9} \mathrm{cells}^{-1}\right)$.

The preferred oxygen regime was tested by incubation of seven $2 \mathrm{ml}$ parallels in $10 \mathrm{ml}$ injection bottles (Ochs $\mathrm{GmbH})$. These were stored inside a gas-tight $1000 \mathrm{ml}$ glass chamber containing a defined headspace gas composition $\left[0,1,2\right.$ or $21 \%$ oxygen in $\mathrm{N}_{2}, 4.0$ calibration gas qualities, (AirLiquide)]. Final $\mathrm{O}_{2}$-concentration in the medium was reached after $24 \mathrm{~h}\left(\mathrm{t}_{0}\right)$. Anoxic conditions were established by flushing the medium and incubation vessel with $\mathrm{N}_{2}$ (AirLiquide) and by the addition of anaerocult plates (Merck AG) as an oxygen scavenger. Suboxic and oxic incubations were flushed twice daily with the appropriate calibrated gas. For each gas concentration, four replicates were prepared, one of which was sacrificed after each of the testing periods $(24,48,72,96$ and $168 \mathrm{~h})$ to count moving and/ or dividing cells. All experiments were incubated at room temperature in the dark.

Amplification and sequencing. To extract genomic DNA, $0.5 \mathrm{ml}$ aliquots of a culture or 5-10 individually picked cells were obtained with a micropipette, washed and processed using the protocol for cultured animal cells of the DNEasy Tissue kit (Qiagen). The SSUrDNA was amplified using the universal eukaryotic primers EukA and EukB (Medlin et al., 1988). For A. marinum and P. alpestris, each amplification contained 10-20 ng of DNA template, 2.5 U HotStar Taq DNA polymerase (Qiagen) in the manufacturer-provided reaction buffer, $1.5 \mathrm{mM} \mathrm{MgCl}, 200 \mu \mathrm{M}$ of each dNTP and $0.5 \mu \mathrm{M}$ of each oligonucleotide primer. The final volume was adjusted to $50 \mu \mathrm{l}$ with sterile distilled water. The PCR protocol for SSU-rDNA amplification consisted of an initial hot start incubation of $15 \mathrm{~min}$ at $95{ }^{\circ} \mathrm{C}$ followed by 30 identical amplification cycles (i.e. denaturing at $95{ }^{\circ} \mathrm{C}$ for $45 \mathrm{~s}$, annealing at $55^{\circ} \mathrm{C}$ for $1 \mathrm{~min}$ and extension at $72{ }^{\circ} \mathrm{C}$ for $2.5 \mathrm{~min}$ ) and a final extension at $72{ }^{\circ} \mathrm{C}$ for $7 \mathrm{~min}$. Negative control reactions included Escherichia coli DNA as a template. The resulting PCR products were cleaned with a PCR MinElute kit (Qiagen) and cloned into a vector using the TA-Cloning kit (Invitrogen). Plasmids were isolated with a Qiaprep Spin Miniprep kit (Qiagen) from overnight cultures and PCR-reamplified using M13F and M13R primers to screen for inserts of the expected size (approx. $1.8 \mathrm{~kb}$ for the SSu-rDNA fragment). For Aristeristoma sp., Phusion polymerase (New England BioLabs) was used for amplification and the products were cloned following the methods of Dunthorn et al. (2008). All clones were sequenced bidirectionally (M13 sequence primers) with a Big Dye Terminator kit (Applied Biosystems) on either an ABI 3100 or 3730 automated sequencer.

Genealogical analyses. We determined and edited haplotypes from overlapping sequence reads in SeqMan (DNASTAR) or CodonCode Aligner v1.2.4 (CodonCode Corporation). Pairwise distances for within and among samples were calculated as uncorrected 'p' distances in PAUP* v4.0b8 (Swofford, 2002). Haplotypes generated here and the environmental sequences from GenBank were placed into the alignment used in Dunthorn et al. (2008), but with most non-Colpodea outgroups removed. The GTR + I + G evolutionary model was selected using hLTR in MrModeltest v2 (Nylander, 2004).

Maximum-parsimony (MP) and maximum-likelihood (ML) analyses were carried out in PAUP ${ }^{*}$ v4.0b8 (Swofford, 2002) with all characters equally weighted and unordered. The TBR heuristic option was used to search trees, running ten random additions with the MulTree option on. Support for MP and ML analyses came from 100 bootstrap replicates using heuristic searches. ML bootstraps were run on the Beowulf cluster at the University of Missouri St. Louis, USA. Bayesian analyses were carried out using MrBayes v3.2.1 (Huelsenbeck \& Ronquist, 2003) with support coming from posterior probability using four chains and running 10 million generations. Trees were sampled every 1000 generations. The first $25 \%$ of sampled trees were considered 'burnin' trees and were discarded prior to tree reconstruction. A $50 \%$ majority rule consensus of the remaining trees was used to calculate posterior probability.

Constrained analysis. In addition to the genealogical analysis above, a ML analysis was carried out with all exemplars in the order Cyrtolophosidida constrained to be monophyletic in PAUP* v4.0b8 (Swofford, 2002); the particular relationships within the Cyrtolophosidida, though, were not specified. The resulting tree was compared with the unconstrained ML tree using a one-tailed KA test (Kishino \& Hasegawa, 1989) as implemented in PAUP ${ }^{*}$ v4.0b8 (Swofford, 2002).

Rate class analyses. Using the full unconstrained alignment, nucleotide positions were partitioned into eight rate classes using HYPY v0.9b (Kosakovsky Pond et al., 2005). The fastest rate class was removed from the alignment and explored using Bayesian analysis as above, except that 3000000 generations were run. The second fastest rate class was then also removed and examined likewise. 


\section{RESULTS}

\section{Description of the neotype of Aristerostoma marinum Kahl, 1931 (Table 2, Figs 1-3)}

While free-swimming, the fast cells spiral, rotating around their longitudinal axis. Cells have no tendency to clump together either while swimming or in the resting state. After a few minutes under the microscope, numerous cells attach either to the water surface or to the coverslip with their posterior ends. In vivo, the ciliate is $9-23 \mu \mathrm{m}$ in length (mean $15 \mu \mathrm{m}, n=29$; measurements rounded to the nearest digit) and 4-11 $\mu \mathrm{m}$ wide (mean $8 \mu \mathrm{m}, n=29$ ) (Table 2). The neotype population of $A$. marinum has an oval shape, tapering towards the anterior end. An oral structure is visible in the anterior third of the cell (Figs $2 b, 3$ ), while the posterior end displays a pulsating vacuole (Fig. 1a). While swimming, it becomes apparent that the left dorsal side is flattened. The cell surface displays prominent longitudinal ribs and on the right lateral side, the cortex carries easily recognizable rows of cilia. Only a few irregularly distributed cilia are recognizable on the dorsal side. In vivo, the somatic cilia are approx. $4 \mu \mathrm{m}$ in length. We did not observe any resting stages in any of our cultures. Reproduction occurs by symmetrogenic binary fission (=perkinetal, Fig. 1b).

All protargol impregnations were suboptimal (Fig. 1c) and only the examination of numerous cells enabled a schematic drawing of protargol-impregnated structures (Fig. 3). Cells are 10-20 $\mu \mathrm{m}$ in length (mean $15 \mu \mathrm{m}, n=47$ ) and $6-10 \mu \mathrm{m}$ wide (mean $=8 \mu \mathrm{m}, n=47)$. The oval-shaped macronucleus is located submedian (in the posterior half of the cell) and has a mean diameter of $3 \mu \mathrm{m}$. In protargol preparations, the micronucleus is sometimes delimited from the macronucleus as a lighter-coloured structure with a mean diameter of $1 \mu \mathrm{m}$ (Fig. 1c). Protargol impregnation does not reveal whether the micronucleus lies within the nuclear membrane. The distribution of extrusomes (mucocysts) in the cell's cortex becomes visible (Fig. 1c). The oral structure appears subapical, but details cannot be resolved using this impregnation. Protargol-impregnated kinetids are displayed in the schematic drawing (Fig. 3). The cell is characterized by six rows of somatic kineties. Kinety 1 consists of six dikinetids extending from the anterior end of the cell $2 / 3$ towards the posterior along the longitudinal axis (Fig. 3); it is located right laterally. Also the right lateral kineties 2 and 3 consist of eight dikinetids each that extend along the complete longitudinal axis from the anterior to posterior poles (Fig. 3). Kinety 4 (right lateral-dorsal) is composed of four dikinetids and three uniciliated kinetids (which are likely to be dikinetids), running from the anterior end of the cell $2 / 3$ towards the posterior along the longitudinal axis (Fig. 3). Kinety 5 (dorsal-left lateral) comprises only two dikinetids located at the anterior end of the cell (Fig. 3). Kinety 6 (left lateralventral) also consists exclusively of dikinetids $(n=8)$, which extend along the whole length of the longitudinal axis and abut the oral apparatus left lateral (Fig. 3). Six kinetids are on the dorsal side. They cannot be assigned to any of the six longitudinal kineties but probably belong to sparsely ciliated somatic kineties (Fig. 2a). As we did not succeed in obtaining appropriate transmission electron micrographs of these kineties, we are not able to define whether we are dealing with mono- or di-kinetids; further TEM work is needed.

\section{Electron microscopy}

SEM confirms the protargol impregnation results (Fig. 2ac) and reveals details of the subapical oral structure of $A$.

Table 2. Morphometric data for the Framvaren Fjord Aristerostoma marinum population

Data are based on live observations, protargol impregnation, SEM and TEM. AV, arithmetic mean; CV, coefficient of variation (\%); MA, macronucleus; max., maximum value; MI, micronucleus; min., minimum value; No., number of observed individuals; SE, standard error; SD, standard deviation; NA, not applicable as characters are invariable.

\begin{tabular}{|lcccccccc|}
\hline Characteristic & Min. & Max. & AV & SD & SE & CV & No. & Method \\
\hline Length $(\mu \mathrm{m})$ & 8.8 & 22.8 & 15.3 & 3.1 & 0.6 & 20.5 & 29 & Live \\
& 10.0 & 19.8 & 14.7 & 2.0 & 0.3 & 13.5 & 47 & Protargol \\
& 8.7 & 15.4 & 12.3 & 2.0 & 0.4 & 16.1 & 23 & SEM \\
Width $(\mu \mathrm{m})$ & 3.6 & 10.7 & 7.6 & 1.8 & 0.3 & 23.6 & 29 & Live \\
& 5.5 & 10.2 & 7.8 & 1.1 & 0.2 & 14.8 & 47 & Protargol \\
No. MA & 5.0 & 9.0 & 7.1 & 0.9 & 0.2 & 13.0 & 23 & SEM \\
No. MI & 1 & 1 & NA & NA & NA & NA & $45 / 3$ & Protargol/TEM \\
Diameter MA $(\mu \mathrm{m})$ & 1 & 1 & NA & NA & NA & NA & $11 / 4$ & Protargol/TEM \\
Diameter MI $(\mu \mathrm{m})$ & 2.2 & 4.5 & 3.3 & 0.6 & 0.1 & 19.1 & 45 & Protargol \\
No. somatic kineties & 1.1 & 1.7 & 1.4 & 0.2 & 0.1 & 12.2 & 11 & Protargol \\
No. oral membranelles & 6 & 6 & NA & NA & NA & NA & $23 / 15$ & SEM/protargol \\
No. kineties of paroral membrane & 4 & 4 & NA & NA & NA & NA & $5 / 15$ & SEM/protargol \\
Distance MA- posterior end & 8 & 8 & NA & NA & NA & NA & 7 & SEM \\
& 4.1 & 9.1 & 6.7 & 1.4 & 0.2 & 20.4 & 45 & Protargol \\
\end{tabular}


(a)

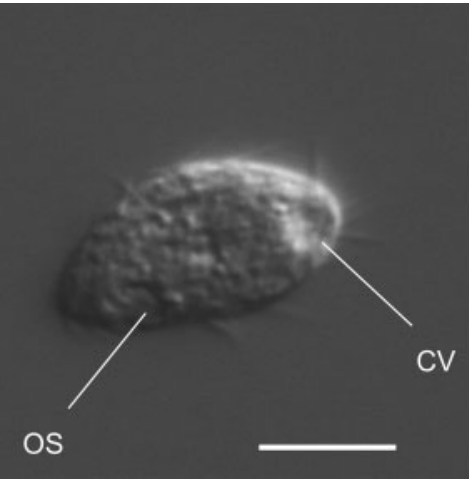

(b)

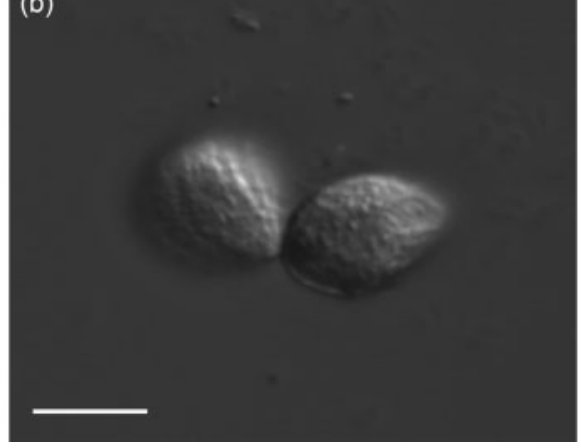

(c)

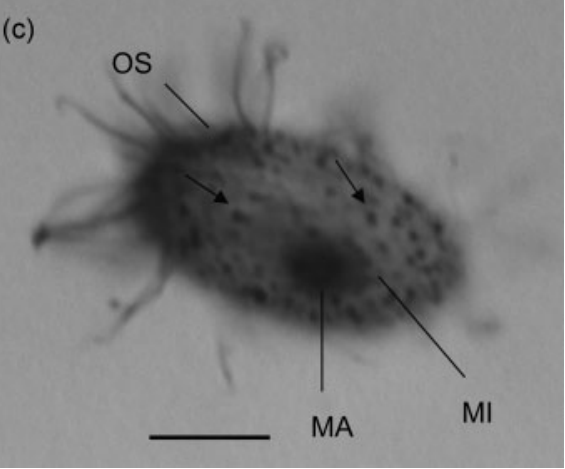

Fig. 1. Light microscopy of living ( $a, b)$ and protargol-impregnated (c) Aristerostoma marinum cells. (a) The contractile vacuole (CV) and the oral structure (OS) are visible during live observations. The photograph shows the left lateral side of the cell. (b) Cell(s) during perkinetal binary fission. (c) Due to poor impregnability (see text and Foissner, 1993) protargol microphotographs are suboptimal. Nevertheless, extrusomes (mucosysts) are clearly visible as dark coloured dots distributed evenly in cortex of the cell (arrows). The macronucleus (MA) and the micronucleus (MI) are visible. Bars, $5 \mu \mathrm{m}$

marinum (Fig. 2b). A gap-less paroral membrane surrounds the triangular oral structure on the right side consisting of five anterior dikinetids and three adjacent posterior monokinetids (bipartite) (Fig. 4). The right margin of the oral structure is bulged and separates the paroral membrane from the oral structure (Figs 2b, 3).

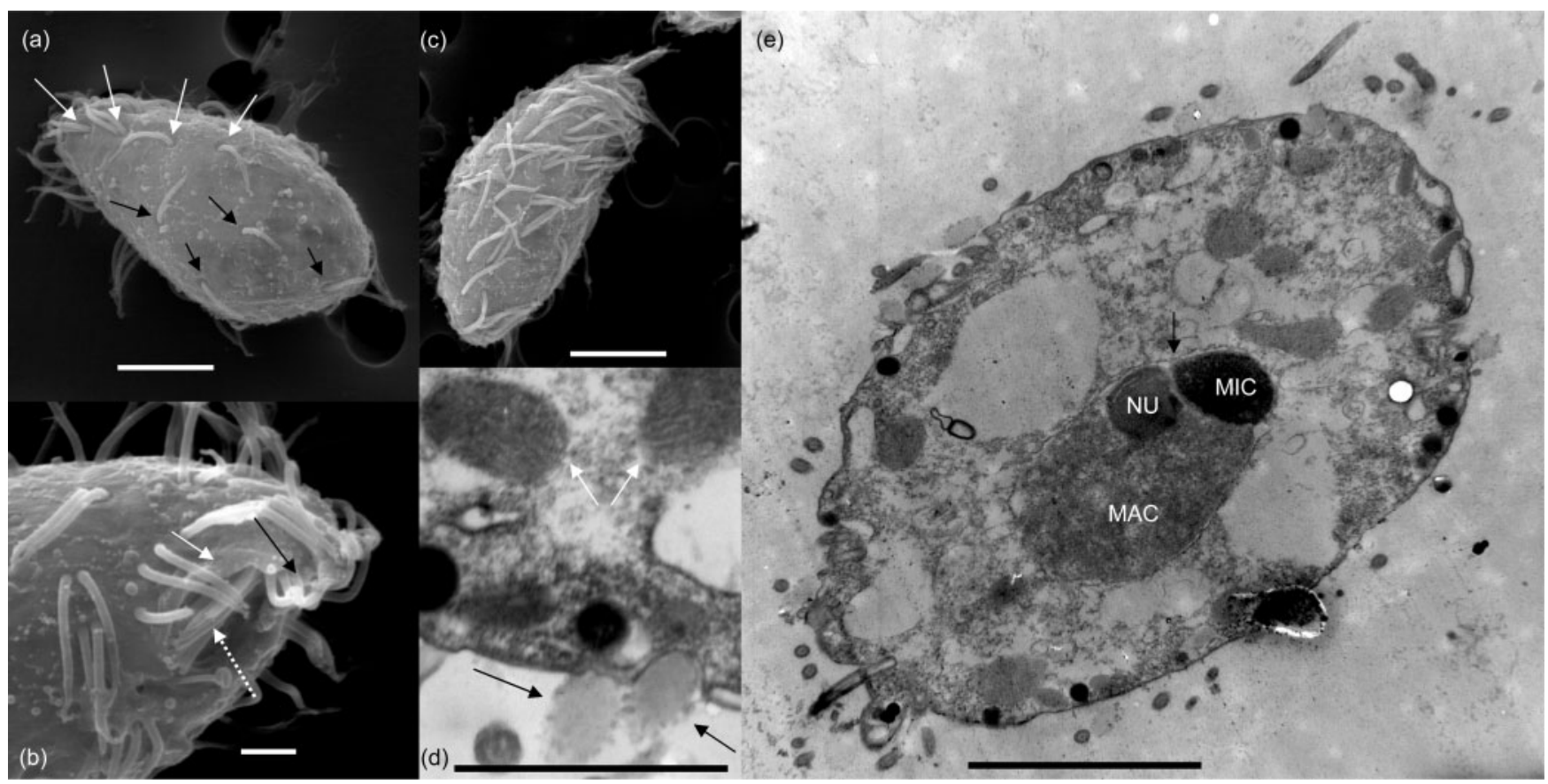

Fig. 2. Scanning $(\mathrm{a}-\mathrm{c})$ and transmission ( $\mathrm{d}, \mathrm{e})$ electron micrographs of Aristerostoma marinum. (a) Left lateral-dorsal view of the cell showing the ellipsoid shape which tapers anteriorly. Parts of kinety number 4 (white arrows, two dikinetids and two uniciliated kinetids are visible, see text for discussion) and four of the six kinetids (black arrows) that seem to belong to sparsely ciliated somatic kineties. (b) Details of the oral apparatus with the bulge (solid white arrow), oral kinetids (black arrow) and the oral membranelle (dashed white arrow). (c) Right lateral view with kineties 1-4 (see schematic drawing Fig. 3). (d) The black arrows point to discharged mucocysts (extrusomes) and the white arrows point to mitochondria with tubular cristae. (e) Longitudinal section of a cell showing the size, position and structure of the nuclear apparatus. The micronucleus (MIC) is distinguished from the nucleolus (NU) by its higher electron density (darker colour). The MIC and macronucleus (MAC) share an outer membrane of the nuclear envelope. However, we were not able to reveal the detailed structure of the nuclear membranes (arrow). Bars: $5 \mu \mathrm{m}$ (a, c, e); $0.5 \mu \mathrm{m}$ (b); $2.5 \mu \mathrm{m}$ (d). 


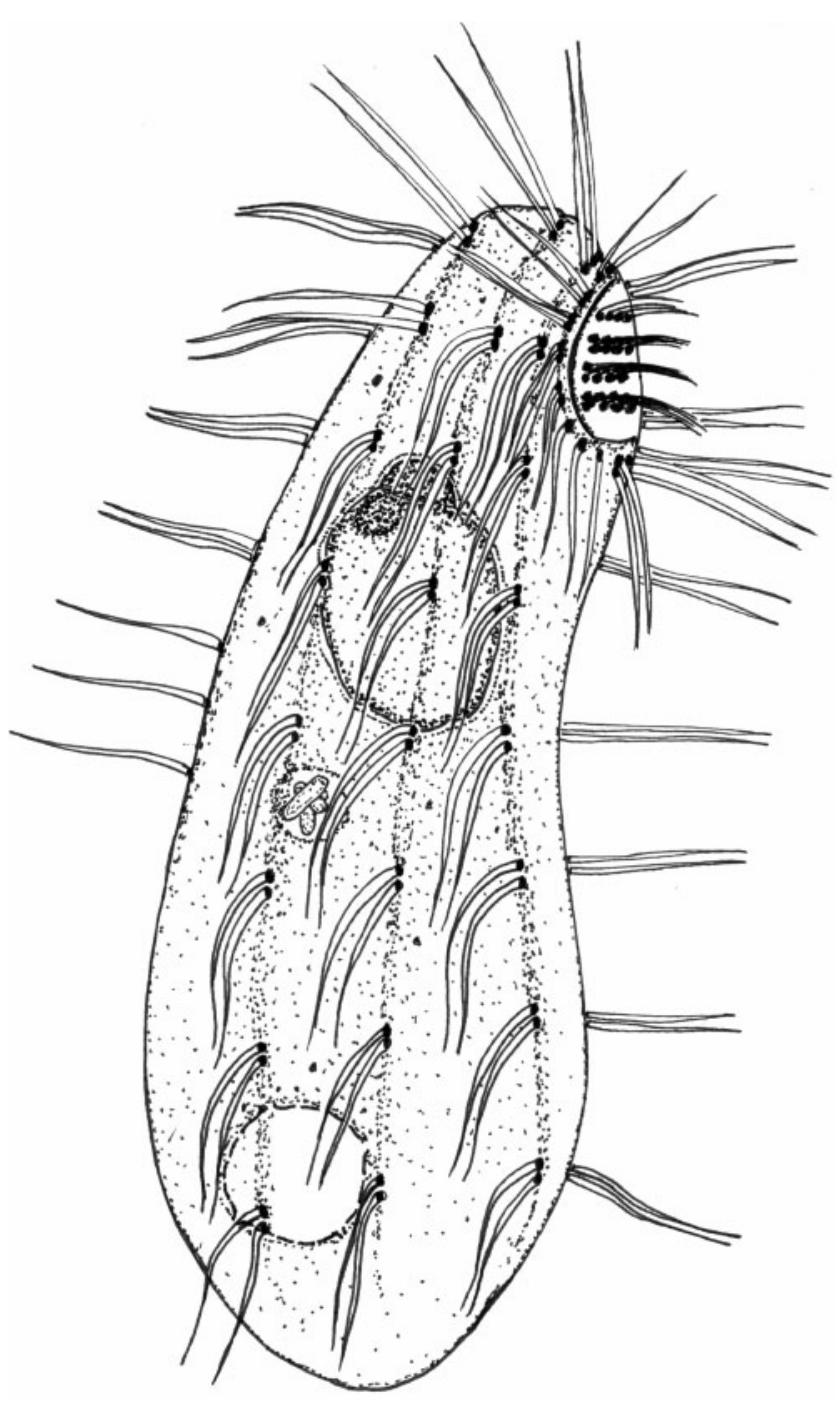

Fig. 3. Schematic drawing of Aristerostoma marinum (right lateral view) that combines the diagnostic features as revealed by live cell imaging, protargol staining and SEM. For details see text.

Four adoral organelles (membranelles 1 to 4 ) originate from the vestibulum. Membranelle 1 consists of four kinetids and emanates in the upper anterior end of the slightly depressed vestibulum. Three more adoral organelles (membranelles 2 to 4 ), each consisting of four kinetids derived from the vestibulum, each comprise two cilia rows. Two additional dikinetids are located right below the posterior end of the oral structure, but could not be assigned to any of the six somatic kineties (Fig. 2a). All dikinetids possess two cilia.

TEM observations (twelve individual cells were analysed) of our collection of A. marinum show numerous extrusomes (mucocysts) located below the pellicle. These mucocysts are highly sensitive and partly discharged during cell fixation. Mitochondria are characterized by tubular cristae (Fig. 2d-e). The micronucleus and the macro- nucleus share an outer membrane of the nuclear envelope; we were not able to clarify the exact organization of this membrane. The nucleolus is located peripherally and is clearly visible as a dense round structure.

\section{Autecology (Fig. 5)}

A. marinum is a bacterivore with a preference for smaller bacteria $(<1 \mu \mathrm{m}$, data not shown). In mixed cultures we did not observe smaller flagellates in the food vacuoles. Laboratory autecological experiments show that the optimal salinity for cell growth is between 35 and $40 \%$, with growth ceasing below 17.5 and above $45 \%$ salinity. Cell growth is highest between $\mathrm{pH} 7$ and 8, with growth ceasing below $\mathrm{pH} 4$ and above $\mathrm{pH} 10$. Cell growth is highest at $28{ }^{\circ} \mathrm{C}$, but stops at temperatures below $12{ }^{\circ} \mathrm{C}$ and at $37^{\circ} \mathrm{C}$. A. marinum is an obligate aerobe with the highest growth rate observed when the level of oxygen is $21 \%$ in the headspace, with growth ceasing at oxygen concentrations below $1 \%$.

\section{Pairwise SSU rDNA sequence differences within the family Cyrtolophosididae}

The mean pairwise distance among the eight Cyrtolophosididae sequences generated here and from GenBank is $5.413 \%$. The pairwise distance between the two Aristerostoma spp. collections is $3.99 \%$. The distances between $P$. alpestris and HAVOmat-euk43 and LKM63 are 0.65 and $0.889 \%$, respectively.

\section{Genealogical analysis}

The SSU-rDNA alignment used for testing the phylogenetic placement of the family Cyrtolophodididae contains 43 sequences, including the three new morphospecies sequenced here: Pseudocyrtolophopsis alpestris and two in the genus Aristerostoma. The alignment has a length of 1623 unmasked nucleotides, 347 of which are parsimony-informative. The most parsimonious tree from the MP analysis is 1580 steps in length, with a Consistency index of 0.48 , and a Homoplasy index of 0.52 . The most likely tree from the ML analysis has a $\ln \mathrm{L}$ of -10080.85 . The most likely tree from the Bayesian analysis has a $\ln \mathrm{L}$ of -10109.04 (Fig. 6).

With the limited outgroups used for this study, the class Colpodea is monophyletic with weak support from all methods of analysis (57 MP bootstrap/- ML bootstrap/ 0.88 Bayesian posterior probability; support less than $50 \%$ or 0.5 is shown as '-'), but see Dunthorn et al. (2008) for an alternative view. Trees generated from each method have largely congruent topologies within the class. In the MP tree, Bryometopus pseudochilodon is basal to its order (plus the order Bursariomorphida), while in the ML and Bayesian trees Bryometopus sphagni is basal. In the Bayesian tree, the chain-forming colpodid Colpoda steinii and the order Grossglockneriida form a clade, although not supported, while in the MP and ML analysis these taxa 


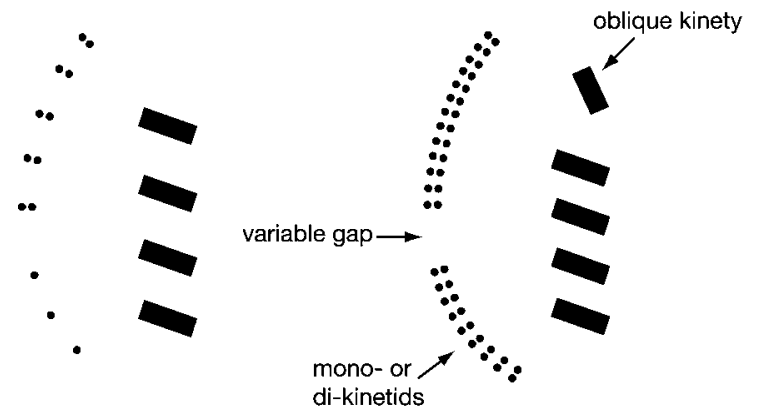

Aristerostoma
Cyrtolophosis
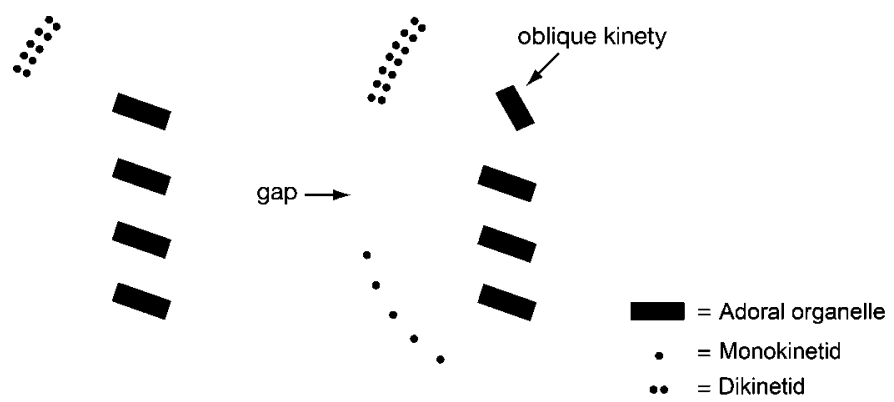

Fig. 4. Schematic drawing of the idealized oral structures (paroral membranes and adoral organelles) of genera in the family Cyrtolophosididae. Note that there can be considerable variation among species within the genera, including in the number and size of adoral organelles. In some species there may be a short oblique kinety situated anteriorly to the uppermost adoral organelle.

form a polytomy with Colpoda aspera and Hausmanniela discoidea.

The order Cyrtolophosidida falls out in two groups with moderate to well supported intervening nodes between them. Cyrtolophosidida I contains all exemplars from the family Cyrtolophosididae and the included environmental samples available from GenBank, with strong to full support from all methods (97/100/1.00). Cyrtolophosidida II contains the remaining exemplars from the order Cyrtolophosidida with the order Sorogenida embedded within them and receives full support from all methods (100/100/1.00).

Relationships among the sampled Cyrtolophosididae are for the most part well resolved. Both Aristerostoma sequences form a clade with full support from all methods (100/100/1.00). The genus Aristerostoma is sister to the rest of the Cyrtolophosididae with high to full support from all methods (92/87/1.00). Cyrtolophosis mucicola is in turn sister to Pseudocyrtolophosis nana and the environmental samples with low support from all methods $(-/ 64 / 0.67)$.

\section{Comparisons of hypotheses}

To compare the morphological hypothesis of Foissner (1993) (where the Cyrtolophosidida is monophyletic) with that of the SSU-rDNA gene tree estimated here (where it is not), the likelihood between the alternative hypotheses was examined. The ML genealogy from the constrained analysis where the Cyrtolophosidida was forced to be monophyletic has a $\ln \mathrm{L}$ of -10221.46 (tree not shown). This likelihood value is 140.61 less than the non-constrained ML genealogy and is rejected by the KA test $(P$ value $<0.000)$ in favour of the non-constrained tree. This indicates further support for the non-monophyly of the Cyrtolophosidida.

\section{Long-branch attraction}

Nucleotides were partitioned into eight rate classes to test the possibility that the non-monophyletic topology of the Cyrtolophosidida is a spurious result due to unequal rates of mutation. If long-branch attraction is affecting the full dataset, then subtracting the fastest evolving nucleotide sites should remove its effect.
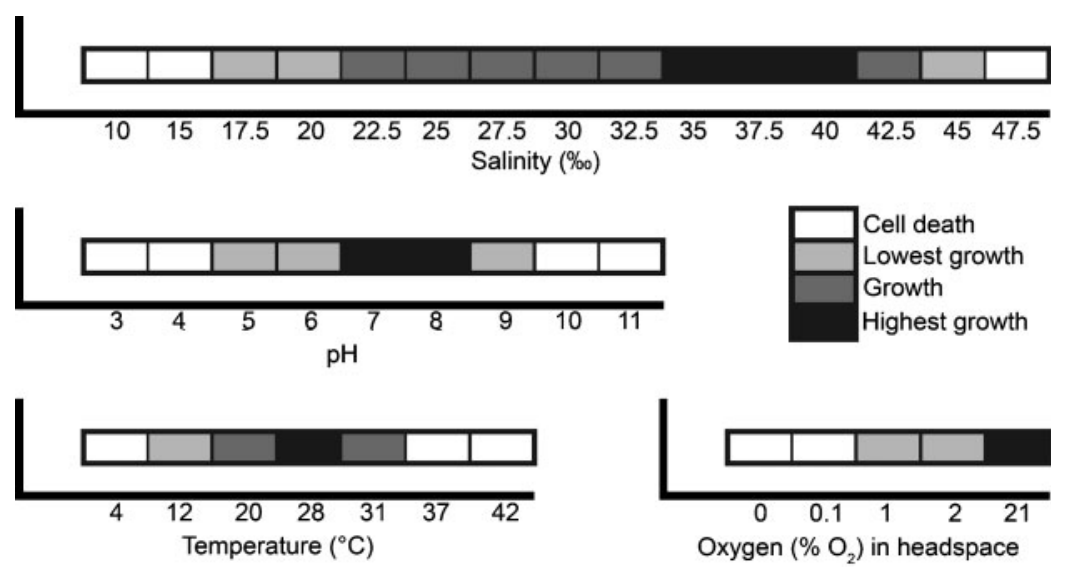

Fig. 5. Ecophysiological tolerance limits of Aristerostoma marinum population Framvaren Fjord. Samples were tested for salinity, $\mathrm{pH}$, temperature and oxygen tolerance. 


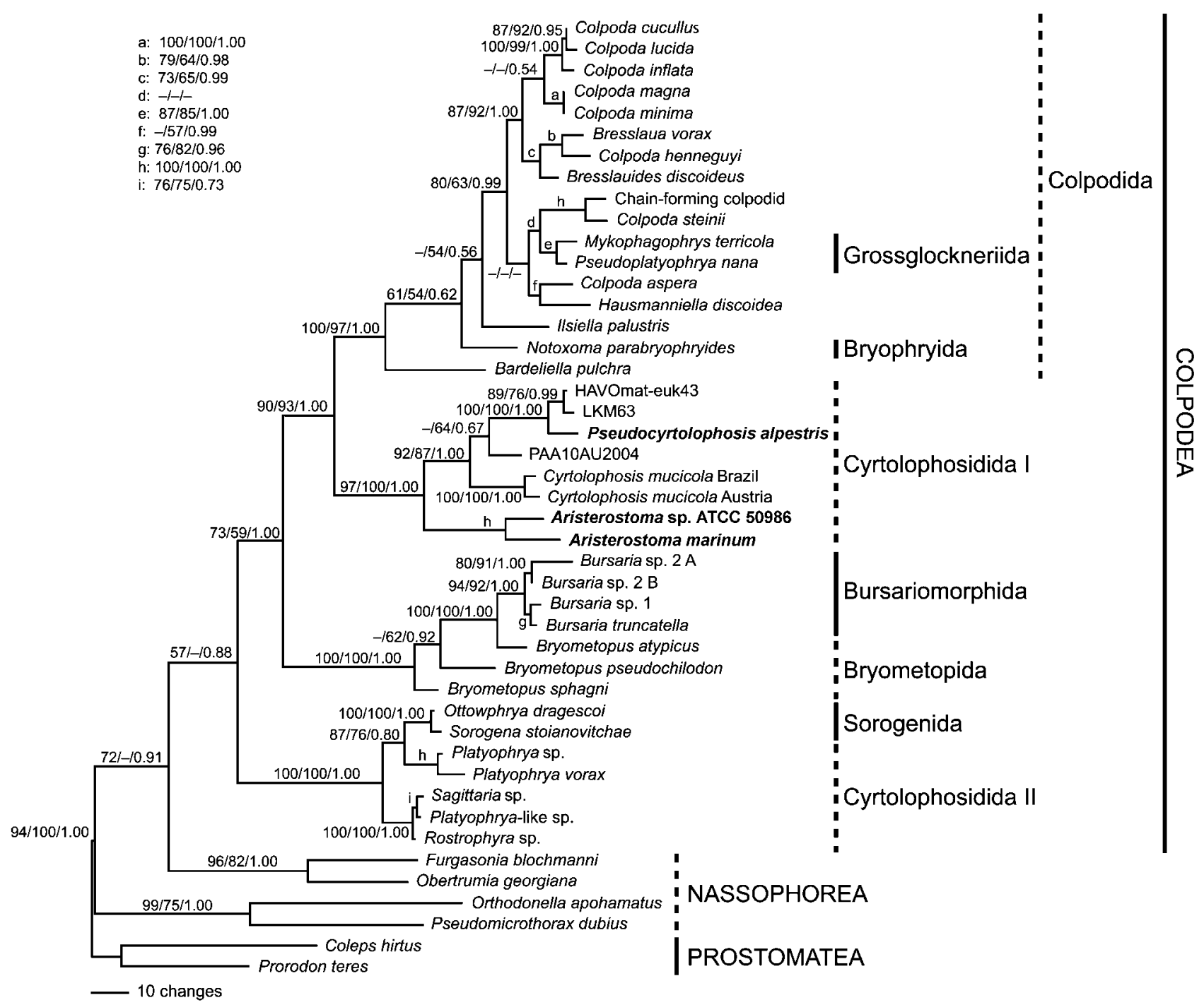

Fig. 6. Most likely Bayesian SSU-rDNA sequence genealogy of the class Colpodea. New sequences are in bold. Numerical support values are shown as: MP bootstrap/ML bootstrap/Bayesian posterior probability. Values $<50 \%$ are shown as '-'. Monophyletic classes and orders are labelled with a solid line, while non-monophyletic ones are labelled with a dashed line. Bar, 10 changes.

The SSU-rDNA alignment with the fastest rate class removed has 1462 unmasked nucleotides, 134 of which are parsimony-informative; the most likely tree from the Bayesian analysis has a $\ln \mathrm{L}$ of -5717.45 (data not shown). The SSU-rDNA alignment with the fastest and second fastest rate classes removed has 1256 unmasked nucleotides, 35 of which are parsimony-informative; the most likely tree from the Bayesian analysis has a $\ln \mathrm{L}$ of -2769.44 (data not shown). In both of these trees much of the structure of the topology is lost among and within clades; however, the Cyrtolophosididae does not branch next to, nor nest within, the other Cyrtolophosidida taxa within either tree. These results support the view that the nonmonophyletic topology of the Cyrtolophosidida is not the result of long-branch attraction.

\section{DISCUSSION}

\section{Neotypification and emended diagnosis of Aristerostoma marinum Kahl, 1931}

1931 Aristerostoma marinum Kahl, Tierwelt Dtl, 21:340

1979 Aristerostoma marinum Detcheva \& de Puytorac, Annales Stn Limnol Besse, 13:247

1993 Aristerostoma marinum Kahl 1931 - Foissner, Protozoenfauna, volume 4/1:557 (revision)

Reference to the neotype Individual specimen marked with a circle on slide 1 at the collection of microscopic slides of the Biology Center at the Upper Austrian Museum 
of Natural History (Linz, Austria), storage code 2007/580582.

Neotype material Neotypified from brackish surface waters of the Framvaren Fjord in south-western Norway

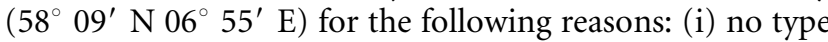
material is available and no type location has been defined; (ii) the existing descriptions are decisively incomplete; (iii) the genus has a proposed subjective junior synonym (Foissner, 1993); (iv) there are several similar species whose identity is threatened by the species to be neotypified; (v) new preparations ('neotype slides') are of a quality allowing the specific features to be clearly recognized. The sample from which we isolated $A$. marinum was taken with a Niskin bottle at a depth of approx. $3 \mathrm{~m}$. At the time of sampling, the temperature of the surface water was $16{ }^{\circ} \mathrm{C}$, salinity was $15 \%$ and the water was saturated with oxygen. Nutrient measurements indicated oligotrophic conditions. The species was isolated directly from the natural sample without prior enrichment.

\section{Emended diagnosis (based on the Framvaren neotype population) Size in vivo 9-23 $\times 4-11 \mu \mathrm{m}$, not contractile, oval shape, tapering anteriorly, one spherical-ellipsoid macronucleus located in the centre of the cell, one smaller spherical-ellipsoid micronucleus, both nuclei share an outer membrane of the nuclear envelope, extrusomes (mucocysts) hardly recognizable in vivo but impregnate well with protargol, six rows of somatic kineties, oral apparatus subapical located anteriorly, oral aperture triangular, four oral membranelles, bipartite paroral membrane on right slope of vestibulum, consists of five anterior dikinetids and three uniciliated kinetids (although they may be dikinetids), one contractile vacuole is located posteriorly, no resting stages observed.}

\section{Detailed description of Framvaren neotype population See results.}

Occurrence and ecology: euryhaline (marine-brackish water), obligate aerobe The type location is not known, but is assumed to be the German Sea coast near Hamburg (Foissner, 1993). Kahl (1931) found A. marinum in infusions (location not defined) and only mentions that it is fairly common and sometimes occurs in high abundances. Detcheva (1982) reported A. marinum from the Bulgarian coast of the Black Sea where it frequently appeared in high numbers. We here define the Framvaren Fjord in Norway as the neotype location. The salinity range of the locations where Detcheva (1982) found A. marinum was 1 to $18 \%$. The salinity of the surface waters in the Framvaren Fjord, where we found A. marinum, was $15 \%$. Interestingly, we did not observe growth of our $A$. marinum population in laboratory experiments below $17 \%$. At present, we do not have an explanation for the discrepancy between the salinity of the population's natural habitat and the growth in the laboratory experiments. In contrast, optimal growth at $\mathrm{pH} \mathrm{7-8}$ under laboratory conditions matches the $\mathrm{pH}$ of the natural habitat ( $\mathrm{pH}$ 7.2). The optimum growth temperature under laboratory conditions is between 20 and $31{ }^{\circ} \mathrm{C}$. Temperatures above $20{ }^{\circ} \mathrm{C}$ are only found in the summer months in the surface waters of the Framvaren Fjord. It is interesting that the laboratory cultures do not survive temperatures below $12{ }^{\circ} \mathrm{C}$ as the temperature of the natural habitat can drop below $5{ }^{\circ} \mathrm{C}$ in the winter months (unpublished data). As we did not observe that this ciliate is capable of forming resting stages, it remains an open question as to how and where these organisms survive the winter temperatures of the Norwegian waters.

Neotype specimens Two neotype slides with protargolimpregnated specimens have been deposited in the collection of microscopic slides of the Biology Center at the Upper Austrian Museum of Natural History (Linz, Austria; storage code 2007/580-582). Live cultures are available from the authors. A circle on slide 1 marks an individual cell that designates the name-bearing type.

\section{Comparison with original descriptions and related species}

The genus Aristerostoma Kahl, 1926 (order Cyrtolophosidida Foissner, 1978, family Cyrtolophosididae Stokes, 1888 ) is diagnosed as very small, laterally flattened and completely ciliated (Foissner, 1993). As pointed out by Foissner (1993), the currently applied diagnostic characters are based on the incomplete description by Kahl (1931). The genus is hardly distinguishable by light microscopy from Cyrtolophosis and Pseudocyrtolophosis, the other two genera within the Cyrtolophosididae. It has been suggested that Pseudocyrtolophosis may in fact be a junior synonym of Aristerostoma, or that both genera may in turn be junior synonyms of Cyrtolophosis (Foissner, 1993). A major reason for an uncertain species identification is a lack of information about the infraciliature leading to an obscured general morphology of the genus Aristerostoma (Foissner, 1993).

One marine and one freshwater species have been described in the genus Aristerostoma by Kahl $(1926,1931)$. Both of the taxa lack type material and modern silver stains. While our findings contrast with the description of A. minutum (habitat, body shape, longitudinal rows, see Foissner, 1993), they agree with the rudimentary morphological description of A. marinum by Kahl (1931) (Table 3) and the ultrastructural description (nuclear and oral structures) of Detcheva \& de Puytorac (1979) as summarized in Foissner (1993). This is based on the position and shape of the macronucleus (spherical, in the centre of the cell) and the position of the contractile vacuole (near the posterior end). The oral apparatus is in the anterior third and bordered on the right by a paroral membrane. On the opposite side of the oral apparatus are four adoral organelles that are composed of two ciliary rows each.

Our analyses revealed the following additional characters of the oral apparatus: (i) the first oral membranelle 
Table 3. Comparative morphology of described representatives of the four genera Cyrtolophosis, Pseudocyrtolophosis, Plesiocaryon and Aristerostoma within the family Cyrtolophosididae (Ciliophora: Colpodea)

Taxa: 1, Cyrtolophosis mucicola Stokes, 1885; 2, Cyrtolophosis minor Vuxanovici, 1963; 3, Pseudocyrtolophosis alpestris Foissner, 1980; 4, Pseudocyrtolophosis terricola Foissner, 1993; 5, Plesiocaryon terricola Foissner, Agatha \& Berger, 2003; 6, Aristerostoma marinum Kahl, 1931; 7, Aristerostoma marinum (this study). DK, dikinetids; MK, monokinetids.

\begin{tabular}{|c|c|c|c|c|c|c|c|}
\hline Characteristic & 1 & 2 & 3 & 4 & 5 & 6 & 7 \\
\hline Length in vivo $(\mu \mathrm{m})$ & $18-30$ & $16-18$ & $16-31$ & $30-45$ & $60-120$ & 30 & $8.8-22.8$ \\
\hline Width in vivo $(\mu \mathrm{m})$ & $8-13$ & $11-15$ & $8-12$ & $12-15$ & $8-12$ & - & $3.6-10.7$ \\
\hline Shape & Ellipsoid to ovoid & Ovoid & $\begin{array}{l}\text { Ellipsoid, dorsally } \\
\text { convex, ventrally } \\
\text { concave }\end{array}$ & $\begin{array}{c}\text { Dorsally convex, ventrally } \\
\text { bent, anterior and } \\
\text { posteriorly slightly } \\
\text { tapering }\end{array}$ & $\begin{array}{c}\text { More or less } \\
\text { vermiform }\end{array}$ & Ellipsoid & $\begin{array}{c}\text { Oval, tapering } \\
\text { anteriorly }\end{array}$ \\
\hline No. somatic kineties & 10 & 8 & 10 & 10 & 10 & - & 6 \\
\hline Position of vacuole & Posterior third & $\begin{array}{l}\text { Postero-lateral, close } \\
\text { to dorsal side }\end{array}$ & Posterior & Posterior & Subterminal & Posterior & Posterior \\
\hline No. oral membranelles & $4+$ oblique kinety & 4 & 4 & 4 & 4 & - & 4 \\
\hline Position oral apparatus & Anterior & Anterior & $\begin{array}{l}\text { Subapical, ventrally } \\
\text { anterior third }\end{array}$ & Anterior & Ventral, anterior & Anterior third & Anterior \\
\hline $\begin{array}{l}\text { Specific characteristics } \\
\text { of oral structure }\end{array}$ & $\begin{array}{l}\text { Paroral membrane } \\
\text { with DK; mostly } \\
\text { discontinuous }\end{array}$ & $\begin{array}{l}\text { Large, encompasses } \\
\text { one third of cell, } \\
\text { circumpolar cilia }\end{array}$ & $\begin{array}{c}\text { Only anterior third with } \\
\text { DK, triangular }\end{array}$ & $\begin{array}{c}\text { Only anterior third } \\
\text { with DK }\end{array}$ & $\begin{array}{c}9 \text { paroral DK; gap } \\
\text { in undulating } \\
\text { membrane }\end{array}$ & $\begin{array}{l}\text { Paroral membrane } \\
\text { consisting of DK }\end{array}$ & $\begin{array}{c}\text { Paroral mem- } \\
\text { brane } 5 \mathrm{DK} \\
\text { and } 3 \mathrm{MK}\end{array}$ \\
\hline $\begin{array}{l}\text { Position of nuclear } \\
\text { apparatus }\end{array}$ & Close to centre of cell & Centre of cell & Posterior half & Centre of cell & Close to centre of cell & Centre of cell & Centre of cell \\
\hline Resting stages & Yes & Unknown & Unknown & Unknown & Unknown & Unknown & Not observed \\
\hline Habitat type & Soil & Soil & $\begin{array}{l}\text { Soil, semiterrestrial }{ }^{\star} \text {, } \\
\text { limnetic }^{*}\end{array}$ & Soil & Soil & Marine & Marine \\
\hline References & Foissner (1993) & Foissner (1993) & Foissner (1993) & Foissner (1993) & Foissner et al. (2002) & Foissner (1993) & This study \\
\hline
\end{tabular}

${ }^{\star}$ Personal observation, W. Foissner, unpublished. 
(membranelle 1) consists only of four monokinetids (Fig. 4); (ii) in contrast to former descriptions (see Foissner, 1993) the paroral membrane is not composed of only dikinetids, but of five anterior dikinetids and three posterior monokinetids and thus, is bipartite (Figs 2b, 3) (iii) the bipartite paroral membrane does not display a gap. Thus, it is very similar but not identical to other genera of the Cyrtolophosididae (Fig. 4). For example, the gap between the anterior and posterior segment of the paroral membrane is highly variable in Cyrtolophosis (Fig. 4, see Fig. 215b in Foissner, 1993) and in Pseudocyrtolophosis about two thirds of the paroral membrane is non-ciliated (Fig. 4, Foissner, 1993). In Plesiocaryon elongatum [=Balantiophorus elongatus Schewiakoff, 1892,= Cyrtolophosis elongata (Schewiakoff, 1892) Kahl, 1931] the bipartite paroral membrane consists of an anterior row of six or seven pairs of kinetosomes whereas the posteriormost is a row of five single kinetosomes both being separated by a distinctive gap (see Fig. 4 and Fig. $1 \mathrm{~b}$ in Diaz et al., 2002). Furthermore, the posterior portion of Plesiocaryon terricola is composed of an average of four widely spaced, barren monokinetids appearing as minute thickenings in vivo (Fig. 4, Foissner et al., 2002). Because of only rudimentary descriptions of $A$. minutum, at this point we are not able to distinguish $A$. marinum from $A$. minutum based exclusively on the oral structure. However, A. marinum is clearly distinct from other genera within the Cyrtholophosididae when the structure of the oral apparatus is considered.

In contrast to Kahl's population $(30 \mu \mathrm{m})$, our type material is on average half as long ( $15 \mu \mathrm{m}$, Tables 2 and 3$)$. Decheva \& de Puytorac (1979), who did not provide a species epithet, gave a length of about $20 \mu \mathrm{m}$. Neither of these earlier descriptions give a value for cell width. Thus, this characteristic is added to the species diagnosis given in this study $(9-23 \mu \mathrm{m}$ in vivo, $10-20 \mu \mathrm{m}$ after protargol). In his first description, Kahl pointed out that he was not able to see the dorsal infraciliature under light microscopy. However, in a schematic drawing, the author shows six longitudinal rows on the right lateral side. Using protargol impregnation and SEM, we can clearly identify six kinety rows with their detailed infraciliature (see Figs 2 and 3). This serves as an additional criterion for the identification of this species, as all other members of the family Cyrtolophosididae possess 8-10 somatic kinety rows (Table 3 ). The detailed infraciliature of A. minutum is unknown but this species seems to have more longitudinal kineties (at least eleven according to the schematic drawing of Kahl, 1931).

We confirmed the observation of Detcheva \& de Puytorac (1979) that the macronucleus and the micronucleus share an outer membrane of the nuclear envelope in the genus Aristerostoma. While they did not identify their isolate down to the species level, here we show that this character state occurs in A. marinum. Since it is not known how widespread the shared outer membrane is distributed in the Cyrtolophosidida, it is important that each species is investigated using SEM (Dunthorn et al., 2008). As for the other species in the genus, we still lack detailed descriptions of division morphogenesis for A. marinum and these will have to be investigated in further studies.

\section{Pairwise distance between Aristerostoma morphospecies}

In this study, we sequenced two different Aristerostoma populations: one from the ATCC, which is an unidentified species, and one isolated from the Framvaren Fjord in Norway, which we identified as A. marinum. As the SSU-rDNA sequences of both taxa have a pairwise difference of $4.285 \%$ they may represent two different species. Thus, future efforts are in order to characterize the ATCC population in detail. This ATCC population is unlikely to be the other known species in the genus, A. minutum, as this is from freshwater.

\section{Phylogenetic placement of the order Cyrtolophosidida}

Increased taxon sampling using the three new morphospecies sequenced here does not support the monophyly of the order Cyrtolophosidida (Fig. 6). Instead, the order divides into two groups that have distinctive oral morphologies. Genera in the clade Cyrtolophosidida I, containing all Cyrtolophosididae sequences, have a nonciliated kinety on the right margin of the adoral organelles and the oral apparatus is located subapically. Genera in the group Cyrtolophosidida II, which contains the remainder of the order plus the order Sorogenida, lack a non-ciliated kinety and the oral apparatus is located at the apical pole (Dunthorn et al., 2008).

To further test the monophyly of the order Cyrtolophosidida, we compared the morphologically based hypothesis of Foissner (1993) for the Cyrtolophosidida with the topology of the SSU-rDNA ML tree produced in this study. An ML analysis of the SSU-rDNA sequences with the nonconstrained topology was significantly more likely to be monophyletic than the constrained topology according the KA test. As for the increased taxon sampling discussed above, this comparison also does not support the monophyly of the Cyrtolophosidida.

\section{Reconciling morphology and molecules}

Here, we focus on arguments presented by Foissner et al. (2004) to discuss why there is disagreement between the morphological classification of the Cyrtolophosidida by Foissner (1993) with that of the SSU-rDNA topology found in this study.

SSU-rDNA sequences are misidentified. The sequences for Cyrtolophosis from Dunthorn et al. (2008) could be from another ciliate. However, we argue that we can reject this argument as the other sequences from the family Cyrtolophosididae found in this study match the Cyrtolophosis sequences more closely than any other ciliate. 
SSU-rDNA sequences are paralogues. Paralogues for protein-coding loci seem to be rampant within ciliates (e.g. Israel et al., 2002; Katz et al., 2004). However, we argue against this as divergent SSU-rDNA paralogues have yet to be reported within ciliates (or at least paralogues in which there has not been concerted evolution).

Insufficient taxon sampling. Insufficient taxon sampling can lead to spurious results (Cummings \& Meyer, 2005; Graybeal, 1998; Hedtke et al., 2006; Hillis, 1998; Hillis et al., 2003; Poe \& Swofford, 1999). We argue that we can reject this argument as we now have eight sequences from the family Cyrtolophosididae (representing three of the four genera in the family) and the same non-monophyletic topology is recovered as in Dunthorn et al. (2008), which only had two sequences from the same morphospecies.

Long-branch attraction. Heterogeneous rates of evolution among branches can lead to spurious results (Felsenstein, 1978). All methods of analyses suffer from this problem to one degree or another (Hendy \& Penny, 1989; Huelsenbeck \& Hillis, 1993; Kolaczkowski \& Thornton, 2004), although the extent of statistical inconsistency in real datasets is questionable (Anderson \& Swofford, 2004; Bergsten, 2005; Siddall \& Whiting, 1999). We argue that we can reject long-branch attraction for our SSU-rDNA dataset for two reasons. First, a visual inspection of the genealogy does not show any protruding single or paired long-branches. Second, successively removing the fastest and second fastest nucleotide sites still produced the same nonmonophyletic topology.

Gene tree versus species tree. The topology of any gene genealogy may not accurately reflect the actual species phylogeny (Doyle, 1992, 1997; Maddison, 1997). Since we only have a single-gene genealogy in this study, we cannot rule out problems caused by incomplete lineage sorting of ancestral alleles.

The Cyrtolophosidida is truly not monophyletic. The Cyrtolophosidida may actually be a non-monophyletic group brought together based on the combination of possibly homoplastic characteristics. If this is indeed the case, then we can suggest two scenarios of morphological evolution: either the members of the Cyrtolophosidida may contain plesiomorphic characters (e.g. oral morphology), or there was convergent evolution along the two branches leading to Cyrtolophosidida I and Cyrtolophosidida II (e.g. shared outer membrane of the nuclear envelope). Further analyses of other loci are needed to test these scenarios.

\section{Assignment of GenBank environmental SSU- rDNA sequences to the Cyrtolophosididae}

In this study, we have also placed cloned haplotypes from previously published molecular environmental diversity surveys into a phylogenetic context in the Colpodea. If we consider the close sequence similarity of HAVOmat-euk43 and LKM63 to P. alpestris, as well as the branching of these sequences inside a well-supported clade (Fig. 6), it is reasonable to assume that these organisms may indeed be tentatively assigned to the genus Pseudocyrtolophosis. It is not possible to say to which species in the genus Pseudocyrtolophosis these organisms should be assigned since LKM63 originates from a freshwater lake in the Netherlands (van Hannen et al., 1999) and HAVOmateuk43 was isolated from a Hawaiian lava cave microbial mat (M. V. Brown and others, unpublished). The morphospecies in Pseudocyrtolophosis have likewise been isolated from a number of terrestrial environments (Foissner, 1993).

Interestingly, the environmental sequence PAA10AU2004, retrieved from a French freshwater lake (Lefèvre et al., 2007), cannot be phylogenetically assigned to any of the sequenced genera within the family Cyrtolophosididae. Thus, it is likely that we are still far from recognizing all of the genera within this family.

Our analyses of the Colpodea demonstrate that increasing the sampling density of known ciliate taxa in phylogenetic studies is needed in order to phylogenetically assign unidentified environmental clones to known ciliate lineages as seen previously in the class Plagyopylea (Stoeck et al., 2007). By doing so, we can make predictive hypotheses of the possible morphology of the ciliates from which the clones are derived, as well as their possible metabolic and ecological roles in the environment from which they were sampled. For example, the environmental clones from previous environmental surveys placed in the family Cyrtolophosididae in this study could be small herbivorous ciliates feeding primarily on bacteria as found for other taxa in this family.

\section{CONCLUSIONS}

Based on our improved observations of A. marinum, it became evident that the genus Aristerostoma is a distinct taxon within the order Cyrtolophosidida. This genus is probably not a junior synonym of other genera in the family, although A. minutum needs to be sampled to support this. A. marinum can be separated from other taxa in the family based on its specific infraciliature and oral structure.

Increased taxon sampling within the family Cyrtolophosididae supported an earlier analysis showing a nonmonophyletic topology of the order Cyrtolophosidida. The family Cyrtolophosididae was again found on a separate branch from the rest of its order. Constrained analyses comparing the likelihood of the morphological placement with that of the SSU-rDNA placement, as well as removal of the fastest evolving sites, also supported this nonmonophyletic topology. However, sampling of other loci is needed to confirm these results.

In the monograph of the class Colpodea, Foissner (1993) describes only one marine species with the remaining taxa 
being freshwater or terrestrial. This study, which places two potentially different species cultured from separate marine environments, points to the possibility of further Colpodea species waiting to be uncovered in future observations of marine habitats.

\section{ACKNOWLEDGEMENTS}

We would like to thank Wilhelm Foissner for the identification of Aristerostoma marinum, for providing the isolate of Pseudocyrtolophosis alpestris and for helpful discussions on the morphology of the family Cyrtolophosididae. We thank Patrick Sweeney for running the ML bootstraps and Dan Lahr, Jan Pawlowski and two anonymous reviewers for insightful comments. Funding for L. A. K. came from NSF grant DEB-043115. Funding for T.S. came from the Deutsche Forschungsgemeinschaft (grant STO414/2-3) and the Stiftung Innovation Rheinland-Pfalz.

\section{REFERENCES}

Anderson, F. E. \& Swofford, D. L. (2004). Should we be worried about long-branch attraction in real data sets? Investigations using metazoan 18S rDNA. Mol Phylogenet Evol 33, 440-451.

Bergsten, J. (2005). A review of long-branch attraction. Cladistics 21, 163-193.

Corliss, J. O. (1961). The Ciliated Protozoa: Characterization, Classification, and Guide to the Literature. Oxford: Pergamon Press.

Corliss, J. O. (1979). The Ciliated Protozoa: Characterization, Classification and Guide to the Literature, 2nd edn. Oxford: Pergamon Press.

Cummings, M. P. \& Meyer, A. (2005). Magic bullets and golden rules: data sampling in molecular phylogenetics. Zoology 108, 329-336.

de Puytorac, P., Perez-Paniagua, F. \& Perez-Silva, J. (1979). A propos d'observations sur la stomatogenèse et l'ultrastructure de cilié Woodruffia metabolica (Johnson et Larson, 1938). Protistologica 15, 231-243.

Detcheva, R. B. (1982). Recherches, en Bulgarie, sur les cilies de certaines plages de la Mer Noire et des rivieres y aboutissant. Annales Stn Limnol Besse 15, 231-253.

Detcheva, R. B. \& de Puytorac, P. (1979). Un nouvel de cilie a micronoyau inclus dans l'enveloppe macronucleaire: le genera Aristerostoma Kahl, 1926. Annales Stn Limnol Besse 13, 247-251.

Díaz, S., Martin-González, A., Borniquel, S. \& Gutiérrez, J. C. (2002). Cyrtolophosis elongata (Colpodea, Ciliophora): Some aspects of ciliary pattern, division, cortical and nuclear changes during encystment and resting cyst ultrastructure. Eur J Protistol 36, 367-378.

Didier, P., De Puytorac, P., Wilbert, N. \& Detcheva, R. (1980). A propos d'observations sur l'ultrastructure de cilié Cyrtolophosis mucicola Stokes, 1885. J Eukaryot Microbiol 27, 72-79.

Doyle, J. J. (1992). Gene trees and species trees: molecular systematics as one-character taxonomy. Syst Bot 17, 144-163.

Doyle, J. J. (1997). Trees within trees: genes and species, molecules and morphology. Syst Biol 46, 537-553.

Dunthorn, M., Foissner, W. \& Katz, L. A. (2008). Molecular phylogenetic analysis of class Colpodea (phylum Ciliophora) using broad taxon sampling. Mol Phylogenet Evol 46, 316-327.

Felsenstein, J. (1978). Cases in which parsimony or compatibility methods will be positively misleading. Syst Zool 27, 401-410.

Foissner, W. (1978). Das Silberliniensystem und die Infraciliatur der Gattungen Platyophrya Kahl, 1926, Cyrtolophosis Stokes, 1885 und
Colpoda O.F.M., 1786: ein Beitrag zur Systematik der Colpidida (Ciliata, Vestibulifera). Acta Protozool 17, 215-231.

Foissner, W. (1985). Klassifikation und Phylogenie der Colpodea (Protozoa: Ciliophora). Arch Protistenkd 129, 239-290.

Foissner, W. (1993). Colpodea (Ciliophora). Protozoenfauna, vol. 4/1, $\mathrm{i}-\mathrm{x}, 1-798$.

Foissner, W. (2002). Neotypification of protists, especially ciliates (Protozoa, Ciliophora). Bull Zool Nom 59, 165-169.

Foissner, W., Berger, H. \& Schaumburg, J. (1999). Identification and ecology of limnetic plankton ciliates. Inf Bayer Landesamt Wasserwirtschaft 3/99, 1-793.

Foissner, W., Agatha, S. \& Berger, H. (2002). Soil ciliates (Protozoa, Ciliophora) from Namibia (Southwest Africa) with emphasis on two contrasting environments, the Etosha Region and the Namib Desert. Denisia 5, 962-967.

Foissner, W., Moon-van der Staay, S. Y., van der Staay, G. W. M., Hackstein, J. H. P., Krautgartner, W.-D. \& Berger, H. (2004). Reconciling classical and molecular phylogenies in the stichotrichines (Ciliophora, Spirotrichea), including new sequences from some rare species. Eur J Protistol 40, 265-281.

Graybeal, A. (1998). Is it better to add taxa or characters to a difficult phylogenetic problem? Syst Biol 47, 9-17.

Hedtke, S. M., Townsend, T. M. \& Hillis, D. M. (2006). Resolution of phylogenetic conflict in large data sets by increased taxon sampling. Syst Biol 55, 522-529.

Hendy, M. D. \& Penny, D. (1989). A framework for the quantitative study of evolutionary trees. Syst Zool 38, 297-309.

Hillis, D. M. (1998). Taxonomic sampling, phylogenetic accuracy, and investigator bias. Syst Biol 47, 3-8.

Hillis, D. M., Pollock, D. D., McGuire, J. A. \& Zwickl, D. J. (2003). Is sparse taxon sampling a problem for phylogenetic inference? Syst Biol 52, 124-126.

Huelsenbeck, J. P. \& Hillis, D. M. (1993). Success of phylogenetic methods in the four-taxon case. Syst Biol 42, 247-264.

Huelsenbeck, J. P. \& Ronquist, F. R. (2003). MrBayes 3: Bayesian phylogenetic inference under mixed models. Bioinformatics 19, 15721574.

ICZN (1999). International Code of Zoological Nomenclature, 4th edn. London, UK: The International Trust for Zoological Nomenclature.

Israel, R. L., Kosakovsky Pond, S. L., Muse, S. V. \& Katz, L. A. (2002). Evolution of duplicated alpha-tubulin genes in ciliates. Evolution 56, $1110-1122$.

Kahl, A. (1926). Neue und wenig bekannte Formen der holotrichen und heterotrichen Ciliaten. Arch Protistenkd 55, 197-438.

Kahl, A. (1931). Urtiere oder Protozoa I: Wimpertiere oder Ciliate (Infusoria) 2. Holotricha außer den im 1. Teil behandelten Prostomata. Tierwelt Dtl 21, 181-398.

Katz, L. A., Lasek-Nesselquist, E., Bornstein, J. \& Muse, S. V. (2004). Dramatic diversity of ciliate histone $\mathrm{H} 4$ genes revealed by comparisons of patterns of substitutions and paralog divergences among eukaryotes. Mol Biol Evol 21, 555-562.

Kishino, H. \& Hasegawa, M. (1989). Evaluation of the maximum likelihood estimate of the evolutionary tree topologies from DNA sequence data and the branching order in Hominoidea. J Mol Evol 29, 170-179.

Kolaczkowski, B. \& Thornton, J. W. (2004). Performance of maximum parsimony and likelihood phylogenetics when evolution is heterogeneous. Nature 431, 980-984.

Kosakovsky Pond, S. L., Frost, S. D. W. \& Muse, S. V. (2005). HyPhy: hypothesis testing using phylogenies. Bioinformatics 21, 676-679. 
Lefèvre, E., Bardot, C., Noël, C., Carrias, J. F., Viscogliosi, E., Amblard, C. \& Sime-Ngando, T. (2007). Unveiling fungal zooflagellates as members of freshwater picoeukaryotes: evidence from a molecular diversity study in a deep meromictic lake. Environ Microbiol 9, 61-71.

Lynn, D. H. (1981). The organization and evolution of microtubular organelles in ciliated protozoa. Biol Rev Camb Philos Soc 56, 243-292.

Maddison, W. P. (1997). Gene trees in species trees. Syst Biol 46, 523-536.

Medlin, L., Elwood, H. J., Stickel, S. \& Sogin, M. L. (1988). The characterization of enzymatically amplified eukaryotes 16S-like ribosomal RNA coding regions. Gene 71, 491-500.

Nylander, J. A. (2004). MrModeltest v2. Distributed by the author. Evolutionary Biology Center, Uppsala University, Uppsala.

Poe, S. \& Swofford, D. L. (1999). Taxon sampling revisited. Nature 398, 299-300.

Reize, I. B. \& Melkonian, M. (1989). A new way to investigate living flagellated/ciliated cells in the light microscope: immobilization of cells in agarose. Bot Acta 102, 145-151.

Siddall, M. E. \& Whiting, M. F. (1999). Long-branch abstractions. Cladistics 15, 9-24.
Stetter, K. O., König, H. \& Stackebrandt, E. (1983). Pyrodictium gen. nov., a new genus of submarine disc-shaped sulphur reducing archaebacteria growing optimally at $105^{\circ}$ C. Syst Appl Microbiol 4, 535-551.

Stoeck, T., Schwarz, M. V. J., Boenigk, J., Schweikert, M., von der Heyden, S. \& Behnke, A. (2005). Cellular identity of an 18 S rRNA gene sequence clade within the class Kinetoplastea: the novel genus Actuariola gen. nov. (Neobodonida) with description of the type species Actuariola framvarensis sp. nov. Int J Syst Evol Microbiol 55, 2623-2635.

Stoeck, T., Foissner, W. \& Lynn, D. H. (2007). Small-subunit rDNA phylogenies suggest that Epalxella antiquorum (Penard, 1922) Corliss, 1960 (Ciliophora, Odontostomatida) is a member of the Plagyopylea. J Eukaryot Microbiol 54, 436-442.

Swofford, D. (2002). PAUP*. Phylogenetic analysis using parsimony ( ${ }^{*}$ and other methods). Sunderland, MA: Sinauer Associates.

van Hannen, E. J., Mooij, W. M., van Agterveld, M. P., Gons, H. J. \& Laanbroek, H. J. (1999). Detritus-dependent development of the microbial community in an experimental system: qualitative analysis by denaturing gradient gel electrophoresis. Appl Environ Microbiol 65, 2478-2484. 